\title{
Bioproductivity and Grain Quality of two Cowpea varieties in Relation to Frequency of Hand Weeding
}

\section{*1 OLAYINKA, BU; ${ }^{1,2}$ LAWAL, AR; ${ }^{1}$ ABDULBAKI, SA; ${ }^{1}$ AYINLA, A; ${ }^{1}$ OLADOKUN, LT; ${ }^{1}$ UDO, OF $;{ }^{1}$ AKINWUNMI, MA; ${ }^{1}$ ETEJERE, EO}

\author{
${ }^{*}$ Department of Plant Biology, Faculty of Life Sciences, University of Ilorin, P.M.B. 1515, Ilorin, Nigeria. \\ ${ }^{2}$ School of Basic and Remedial Studies, Kwara State College of Education, P. M. B. 1527, Ilorin, Kwara State \\ *Corresponding Author Email: olayinka.bu@unilorin.edu.ng
}

\begin{abstract}
The concern for human health and safety coupled with the increase in herbicides resistant weeds necessitated the need to investigate the effect of frequency of hand weeding on weed suppression, productivity and grains quality in two varieties of cowpea ( $\operatorname{Tvx} 3236$ and Ife brown). Plot layout was a split-plot arrangement in complete randomized block design with three replications. The cowpea lines were subjected to five treatments of frequency of hand weeding. Data on weed and crop were subjected to Analysis of Variance. Means were separated using Duncan Multiple Range Test at 0.05 level of significance. Weed species that were found to be preponderant include Brachiaria deflexa, Euphorbia heterophylla and Commelina benghalensis. The three hand weeding at 3, 6 and 9 weeks after planting (WAP) showed the highest weed control efficiency of $90.48 \%$ followed by those of two hand weeding at 3 and 6 WAP ( $86.98 \%)$ and one hand weeding at 3 WAP (74.68\%). The weed free check was the most effective in controlling weeds $(93.80 \%)$. Growth and productivity of the two cowpea lines were enhanced with increase in frequency of hand weeding when compared with the weedy check. Weeds reduced crop yield by $56.17 \%$. The results of grain quality such as crude protein, lipid content, ash and crude fibre were also enhanced with increase in frequency of hand weeding. Generally, growth and yield were higher in Ife brown than Tvx3236. The research was limited to one cropping season and there is need for reproducibility for consistent of results. The study concluded that weeding twice and three times were found to be feasible since these frequencies of weeding times promoted effective weed reduction, higher growth, and yield and grain quality of the two cowpea varieties studied.
\end{abstract}

DOI: $\underline{\text { https://dx.doi.org/10.4314/jasem.v23i6.3 }}$

Copyright: Copyright (C) 2019 Olayinka et al. This is an open access article distributed under the Creative Commons Attribution License (CCL), which permits unrestricted use, distribution, and reproduction in any medium, provided the original work is properly cited.

Dates: Received: 29 April 2019; Revised: 04 June 2019; Accepted 13 June 2019

Keywords: growth and yield, proximate composition, three hand weeding, cowpea productivity.

Cowpea (Vigna unguiculata (L) Walp) is a widely cultivated leguminous crop in the savanna region of West Africa (Muoneke,et al., 2012). It is a dicotyledoneae, belonging to the order Fabaceae, subfamily Fabioceae, tribe Phasioleae, sub-tribe Phasiolenae and genus Vigna (Singh, 2002; Padulosi and $\mathrm{Ng}, 1997)$. Cowpea constitutes a valuable source of protein (Ayodele and Yalwa, 2005).In Nigeria, especially in the South-eastern region, the production of cowpea is not widespread due to some constrains such as diseases, insect pests and parasitic weeds, low soil fertility coupled with the paucity of information on adapted varieties (Ogbuinya, 1997). Yield loss in cowpea due to weeds has been reported to range from $41-80 \%$ and reduction of grain yield of cowpea over the entire period of growth has been found to be as high as $50-70 \%$ as a result of uncontrolled weeds. The first 3-4 weeks of cowpea growth are critical since failure to commence weed control will lead to significant yield loss (Akobundu, 2005). Bhan et al., (2003), reported that two hand weeding within the first
5 weeks of cowpea growth are necessary to minimize weed competition and yield reduction. It is acknowledged that different studies on weed control methods have been examined but weeds continue to render havoc to the efforts geared towards the use of hand weeding. Hence, the present study was designed to evaluate the optimum number of times hand weeding should be carried out to maximize cowpea productivity in term of growth, yield and nutritional composition of the grain. This will limit the need for peasant farmers to heavily rely on herbicides which have been found unsafe for the environment.

\section{MATERIALS AND METHODS}

Site description: The study was carried out at the Botanical Garden, University of Ilorin, Nigeria in September, 2016. Two varieties of cowpea (Vigna unguiculata) seeds (Tvx 3236 and Ife brown) were collected at Kwara State Agricultural Development Programme in Ilorin. Healthy seeds with intact seed coat were selected for sowing. The studied site is

*Corresponding Author Email: olayinka.bu@unilorin.edu.ng 
located in Southern Guinea savannah containing broad leaf, grass and sedge weeds, with low and smooth topography. The experimental soil was loamy sand with slightly alkaline $\mathrm{pH}$. The organic matter is moderately high $(2.17 \%)$, moderate in nitrogen $(0.50 \%)$ and Effective Cation Exchangeable Capacity $(3.50 \mathrm{cmol} / \mathrm{kg})$.

Experimental Layout, Treatment Details and Crop Management: Each experimental unit had a field dimension of $1 \mathrm{~m}$ by $1 \mathrm{~m}$ containing four rows. The plots were arranged in a completely randomized block design in which the treatments were replicated thrice. Two seeds were sown per hole at depth of $0.03 \mathrm{~m}$ with inter-row spacing of $0.4 \mathrm{~m}$ and plant to plant spacing of $0.2 \mathrm{~m}$. Weeding was carried out by hand throughout the period of the investigation. The experiment comprises five weed control treatments: $\mathrm{T}_{1}=$ One hand weeding at 3 week after planting (WAP), $\mathrm{T}_{2}=$ Two hand weeding at 3 and $6 \mathrm{WAP}, \mathrm{T}_{3}=$ three hand weeding at 3, 6 and $9 \mathrm{WAP}, \mathrm{T}_{4}=$ Weed free (positive control) and $\mathrm{T}_{5}=$ Weedy check (negative control). Twenty millilitres $20 \mathrm{ml}$ (karate) per 15 litres of water was applied using Knapsack sprayer at 6,9 and 12 weeks after planting to prevent pest infestation.

Data Collection :(a) Weed and crop: A $1 \mathrm{~m}^{2}$ area quadrat was randomly placed at two spots in each each experimental unit. Weed scoring was done while the weeds encountered were identified to species level at the Herbarium unit of Plant Biology Department, University of Ilorin. The total weed density in each experimental unit was estimated at 3,6 and 9 using the formula below:

$$
\text { weed density }=\frac{\text { average of all weed species }}{\text { area of quadrat }}
$$

The harvested weeds were air dried to record the weed biomass using MP 1001 electronic balance with precision of $0.1 \mathrm{~g}$. The weed control efficiency (WCE) was calculated,

$$
\text { WCE }=\frac{\text { weed dry weight of the unweeded control }- \text { weed dry weight of weeded treatment }}{\text { weed dry weight of the unwanted control }} \times 100
$$

Morphological growth parameters such as plant height, number of leaves, number of primary branches, stem girth were estimated at harvest. Physiological growth character such as leaf area, dry matter production by oven-drying at $75^{\circ} \mathrm{C}$, leaf area ratio (LAR), relative growth rate (RGR) were also estimated. Reproductive parameters such as number of matured pods per plant, pod-weight and yield in kilograme per hectare were estimated.

(b) Seed Quality and proximate Composition: Proximate compositions (moisture, ash, crude fibre, fat, crude protein and carbohydrate) were done at Nigeria Stored Product Research Institute (NSPRI) following the methods of Association of Official Analytical Chemists (AOAC, 2000).Cowpea seeds (Tvx 3236 and Ife brown) were ground and analysed for proximate composition.
Moisture content was determined using $1.0 \mathrm{~g}$ of the sample kept in oven for over 5 days, then removed and reweigh after cooling. Crude fibre was determined by boiling the $3.0 \mathrm{~g}$ of the sample and sulphuric acid $\left(\mathrm{H}_{2} \mathrm{SO}_{4}\right)$ for 30 minutes in conical flask to remove digestible nutrients. The obtained mixture was filtered and eventually watched with distilled water, hydrochloric acid and ethanol leaving acid-free residue which was transferred into a muffle furnace at $600^{\circ} \mathrm{C}$ for 30 minutes. The crucible is then removed from desiccator and weighed after cooling. Ash was determined by oven-drying of $5.0 \mathrm{~g}$ of the sample at $100^{\circ} \mathrm{C}$, and thereafter transferred to muffle furnace at $555^{\circ} \mathrm{C}$. The crucible was removed from desiccator and weigh after cooling. Crude protein determined using micro-Kjeldahl method as shown below:

$$
\begin{gathered}
\% \mathrm{~N}(\text { Wet })=(\mathrm{A}-\mathrm{B}) \times 1.4007 \times 100 \text { divided by weight }(\mathrm{g}) \text { of sample } \\
\mathrm{A}=\text { Volume of }(\mathrm{ml}) \text { std } \mathrm{HCl} \times \text { Normality of std } \mathrm{HCl} \\
\mathrm{B}=\text { Volume of }(\mathrm{ml}) \text { std } \mathrm{NaOH} \times \text { Normality of std } \mathrm{NaOH}
\end{gathered}
$$

Fat was determined gravimetrically where $5.0 \mathrm{~g}$ of sample was weighed into thimble, 3 hours, petroleum ether $\left(40-60^{\circ} \mathrm{C}\right)$ was used to carry out extraction for 3 hours. The percentage fat was calculated using the formula depicted below:

$$
\text { Fat }(\%)=\frac{\text { Weight of fat }}{\text { Weight of sample }} \times 100
$$

Carbohydrate was determined by difference as shown below: 
Total carbohydrate $=100-(\%$ fat $+\%$ ash $+\%$ moisture $+\%$ protein $+\%$ crude fibre)

Data Analysis: The data recorded were subjected to Univariate Analysis of Variance using Statistical Package for Social Science. Treatment means were separated using Duncan Multiple Range Test (1995) at $\mathrm{P}<0.05$ level of significance.

\section{RESULTS AND DISCUSSION}

Weed Flora Composition: A total of twenty two weed species were encountered (Table 1). Broad-leaved weeds (annual) occurred in greater number than annual and perennial grasses. This could be attributed to lack of satisfactory weed control, most importantly where one hand weeding at 3WAP. Similar observations have been reported by Olayinka et al. (2017) in their studies of weed control in tomato. The most preponderant families were Poaceae Fabaceae and Asteraceae. The most abundant weed species during the experiment were Brachiaria deflexa (14.82\%) followed by Euphorbia heterophylla (13.04) while the least is Vernonia galamensis $(0.8 \%)$. The weeds species had been found to be predominant in most annual crops (Olayinka, et al., 2017

Table 1: Weed species of the experimental site plots and their relative abundance frequency under weed control methods in

\begin{tabular}{|c|c|c|c|c|}
\hline \multicolumn{5}{|c|}{ Vignaunguiculata } \\
\hline $\mathbf{S} / \mathbf{N}$ & Weed species & Life cycle & Relative abundance & Family \\
\hline 1. & Aspolliaafricana(Pers). & $\mathrm{ABL}$ & 5.33 & Asteraceae \\
\hline 2. & Brachiariadeflexa(Schum.) C.E Hubbard. & $\mathrm{AG}$ & 14.82 & Poaceae \\
\hline 3. & Brachiaria lata (Schum) C.E Hubbard. & $\mathrm{AG}$ & 1.04 & Poaceae \\
\hline 4. & BulbostylisabortivaSteudel C.B Clarke. & $\mathrm{AG}$ & 8.42 & Poaceae \\
\hline 5. & Cassia mimosoidesLinn. & $\mathrm{ABL}$ & 3.65 & Fabaceae \\
\hline 6. & Commelinabenghalensis Linn. & PBL & 10.91 & Commelinaceae \\
\hline 7. & Commelinadifusa. Linn & PBL & 1.43 & Commelinaceae \\
\hline 8. & Cynodondactylon Linn. & PG & 1.73 & Poaceae \\
\hline 9. & Cyperusrotundus Linn. & PS & 4.53 & Cyperaceae \\
\hline 10. & Dactyloteniumaegyptium Linn. & $\mathrm{AG}$ & 1.36 & Poaceae \\
\hline 11. & Euphorbia heterophylla Linn & $\mathrm{ABL}$ & 13.04 & Euphorbiaceae \\
\hline 12. & Hibiscus asper. Hook. F. & $\mathrm{ABL}$ & 0.89 & Malvaceae \\
\hline 13. & Mimmosapudica Linn. & PBL & 1.08 & Fabaceae \\
\hline 14. & Oldenlandiaherbaceae Linn. & $\mathrm{ABL}$ & 5.82 & Rubiaceae \\
\hline 15. & Parkiabiglobosa (Jacq).G.Don. & $\mathrm{ABL}$ & 1.12 & Fabaceae \\
\hline 16. & Pennisetumviolaceum (Lam) L. Rich. & $\mathrm{AG}$ & 9.47 & Poaceae \\
\hline 17. & Phyllanthusamarus Schwann and Thonn. & $\mathrm{AG}$ & 2.60 & Euphorbiaceae \\
\hline 18. & Rhynchelytrumrepens (wild) C. E. Hubbard & $\mathrm{AG}$ & 0.86 & Poaceae \\
\hline 19. & Tephrosiabracteolata (Guill and pers). & $\mathrm{ABL}$ & 7.3 & Fabaceae \\
\hline 20. & Tridaxprocumbens Linn. & $\mathrm{ABL}$ & 2.8 & Asteraceae \\
\hline 21. & VernoniagalamensisSchumach) Lip. & $\mathrm{ABL}$ & 0.8 & Asteraceae \\
\hline 22. & Vernoniaperrottetti (Schumach) Lip. & $\mathrm{ABL}$ & 1.04 & Asteraceae \\
\hline
\end{tabular}

N.B: $* 9.6 \%$ and above $=$ Very abundant $; 4.6-9.5 \%=$ Abundant $;(<4.5 \%)=$ Less abundant $;$ ABL $=$ Annual Broad Leaf; PBL $=$ Perennial Broad Leaf; $P G=$ Perennial Grass; $P S=$ Perennial Sedge

Table 2: Weed density, weed biomass and weed control efficiency of two varieties of cowpea - Tvx3236 and Ife brown as influenced by frequency of hand weeding

\begin{tabular}{lllll}
\hline Variety & Treatment & $\begin{array}{l}\text { Weed density } \\
\left(\mathbf{m}^{-2}\right)\end{array}$ & $\begin{array}{l}\text { Weed } \\
\text { biomass }(\mathbf{g})\end{array}$ & $\begin{array}{l}\text { Weed control } \\
\text { Efficiency }(\%)\end{array}$ \\
\hline Tvx 3236 & $\mathrm{T}_{1}$ & $7.42^{\mathrm{b}}$ & $85.00^{\mathrm{b}}$ & $79.63^{\mathrm{d}}$ \\
& $\mathrm{T}_{2}$ & $5.21^{\mathrm{c}}$ & $55.33^{\mathrm{c}}$ & $86.70^{\mathrm{c}}$ \\
& $\mathrm{T}_{3}$ & $3.40^{\mathrm{d}}$ & $40.0^{\mathrm{d}}$ & $90.33^{\mathrm{b}}$ \\
& $\mathrm{T}_{4}$ & $2.20^{\mathrm{e}}$ & $28.43^{\mathrm{e}}$ & $93.13^{\mathrm{a}}$ \\
& $\mathrm{T}_{5}$ & $10.91^{\mathrm{a}}$ & $419.67^{\mathrm{a}}$ & $0.00^{\mathrm{e}}$ \\
& Mean & 5.83 & 125.69 & 69.96 \\
& $\mathrm{p}$-value & 0.002 & $<0.001$ & $<0.001$ \\
& $\mathrm{~T}_{1}$ & $6.23^{\mathrm{b}}$ & $122.33^{\mathrm{b}}$ & $70.03^{\mathrm{d}}$ \\
& $\mathrm{T}_{2}$ & $4.94^{\mathrm{c}}$ & $51.67^{\mathrm{c}}$ & $87.27^{\mathrm{c}}$ \\
& $\mathrm{T}_{3}$ & $3.02^{\mathrm{d}}$ & $38.33^{\mathrm{d}}$ & $90.62^{\mathrm{b}}$ \\
& $\mathrm{T}_{4}$ & $2.01^{\mathrm{e}}$ & $25.33^{\mathrm{e}}$ & $93.80^{\mathrm{a}}$ \\
& $\mathrm{T}_{5}$ & $9.75^{\mathrm{a}}$ & $408^{\mathrm{a}}$ & $0.00^{\mathrm{e}}$ \\
& Mean & 5.19 & 129 & 68.60 \\
& $\mathrm{p}$-value & 0.003 & $<0.001$ & $<0.001$
\end{tabular}

N. B: Means in the same column having the same superscripts are significantly the same at $p<0.05 . T_{1}=$ One hand weeding at 3 WAP, $T_{2}=$ Two hand weeding at 3 and $6 \mathrm{WAP}, T_{3}=$ three hand weeding at 3, 6 and $9 \mathrm{WAP}, T_{4}=$ Weed free (positive control) and $T_{5}=$ Weedy check (negative control).

OLAYINKA, BU; LAWAL, AR; ABDULBAKI, SA; AYINLA, A; OLADOKUN, LT; UDO, OF; AKINWUNMI, MA; ETEJERE, EO 
Weed Control Effort: Weed biomass, weed control efficiency and weed density were significantly affected by the weed control methods (Table 2). Weed biomass was highest in the weedy check with values of $419.67 \mathrm{gm}^{-2}$ and $408.33 \mathrm{gm}^{-2}$ but lowest in the weed free check with values of 28.43 and 25.33 in Tvx3236 and Ife brown respectively. The higher biomass observed in the weedy check could be attributed to uncontrolled weeds measure on weed growth (Dadari, 2003; Olayinka and Etejere, 2015), Significant highest weed control efficiency was recorded in weed free check for both varieties (93.14-93.80\%) followed by three hand weeding at 3,6 and 9 WAP, two hand weeding at 3 and $6 \mathrm{WAP}$ and one hand weeding at 3 WAP. Weedy check recorded significantly lower weed control efficiency over all other treatments. This trend agreed with the findings of Olayinka and Etejere (2015) in their studies of weed control methods in arable crop. Weed density is considerably low in the weed control treatments. The weedy check in Tvx 3236 and Ife brown recorded higher values of weed density of $10.91 \mathrm{gm}^{-2}$ and $9.75 \mathrm{gm}^{-2}$ respectively when compared to other treatments. This observed results could be partly due to unchecked growth of early and late emerging weeds in weedy check. This result is line with earlier workers such as Mathew and Screenivasan, (1998), Getachew et al, (2017) and Khan et al., (2004) who have consistently reported maximum weed density in weedy check.

Growth Response: Growth parameters such as plant height, number of leaves, leaf area and dry matter of the two varieties studied at harvest were significantly $(\mathrm{P}<0.05)$ increased in the weed control treatments (Table 3). The weedy check recorded the lowest values of all the growth attributes mentioned above (Table 3). The higher growth attributes recorded from the weed free check, three hand weeding at 3, 6 and 9 WAP, two hand weeding at 3 and 6 WAP and one hand weeding at 3 WAP could be due to low incidence of weeds competition. The results were in agreement with the reports of Odeleye et al. (2007) and Reddy and Whiting, (2000) who variously reported that higher plant growth observed are due to less weed competition for scarce resources that are needed for crop to thrive.

Table 3: Plant height, number of leaves, leaf area and dry matter in Tvx 3236 and Ife brown as influenced by different weed control methods

\begin{tabular}{|c|c|c|c|c|c|}
\hline \multirow{2}{*}{$\begin{array}{l}\text { Variety } \\
\text { Tvx } 3236\end{array}$} & \multirow{2}{*}{$\begin{array}{l}\text { Treatment } \\
T_{1}\end{array}$} & \multirow{2}{*}{$\begin{array}{l}\begin{array}{l}\text { Plant height } \\
\text { (m) }\end{array} \\
40.85^{\mathrm{d}}\end{array}$} & \multirow{2}{*}{$\begin{array}{l}\text { Number of leaves } \\
61.00^{c} \text { At harves }\end{array}$} & Leaf area $\left(\mathrm{m}^{2}\right)$ & \multirow{2}{*}{$\begin{array}{l}\text { Dry matter (g) } \\
43.90^{\mathrm{c}}\end{array}$} \\
\hline & & & & $52.40^{\mathrm{d}}$ & \\
\hline & $\mathrm{T}_{2}$ & $51.40^{\mathrm{c}}$ & $78.67^{\mathrm{b}}$ & $57.50^{\mathrm{c}}$ & $50.80^{\mathrm{b}}$ \\
\hline & $\mathrm{T}_{3}$ & $56.25^{\mathrm{b}}$ & $93.33^{\mathrm{a}}$ & $62.97^{\mathrm{b}}$ & $56.00^{\mathrm{a}}$ \\
\hline & $\mathrm{T}_{4}$ & $58.03^{\mathrm{a}}$ & $97.67^{\mathrm{a}}$ & $63.37^{\mathrm{a}}$ & $56.43^{\mathrm{a}}$ \\
\hline & $\mathrm{T}_{5}$ & $32.90^{\mathrm{e}}$ & $42.00^{\mathrm{d}}$ & $39.20^{\mathrm{e}}$ & $29.00^{\mathrm{d}}$ \\
\hline & Mean & 1547.89 & 74.53 & 55.09 & 47.24 \\
\hline & p-value & 0.01 & 0.003 & $<0.001$ & $<0.001$ \\
\hline \multirow[t]{7}{*}{ Ife brown } & $\mathrm{T}_{1}$ & $44.20^{\mathrm{d}}$ & $58.33^{\mathrm{d}}$ & $60.00^{\mathrm{c}}$ & $50.01^{\mathrm{d}}$ \\
\hline & $\mathrm{T}_{2}$ & $52.10^{\mathrm{c}}$ & $66.40^{\mathrm{c}}$ & $67.97^{\mathrm{bc}}$ & $57.10^{\mathrm{c}}$ \\
\hline & $\mathrm{T}_{3}$ & $64.00^{\mathrm{b}}$ & $82.00^{\mathrm{b}}$ & $73.90^{\mathrm{b}}$ & $62.54^{\mathrm{b}}$ \\
\hline & $\mathrm{T}_{4}$ & $65.54^{\mathrm{a}}$ & $85.00^{\mathrm{a}}$ & $75.80^{\mathrm{a}}$ & $63.90^{\mathrm{a}}$ \\
\hline & $\mathrm{T}_{5}$ & $34.20^{\mathrm{e}}$ & $40.67^{\mathrm{e}}$ & $40.80^{\mathrm{d}}$ & $30.83^{e}$ \\
\hline & Mean & 52.01 & 66.48 & 63.49 & 52.88 \\
\hline & p-value & 0.003 & 0.003 & $<0.001$ & $<0.001$ \\
\hline
\end{tabular}

N. B: Means in the same column having the same superscripts are not significantly different at $(\mathrm{P}<0.05)$. $\mathrm{T}_{1}=\mathrm{One}$ hand weeding at $3 \mathrm{WAP}$, $\mathrm{T}_{2}=$ Two hand weeding at 3 and $6 \mathrm{WAP}, \mathrm{T}_{3}=$ three hand weeding at 3,6 and 9 WAP, $\mathrm{T}_{4}=$ Weed free (positive control) and $\mathrm{T}_{5}=$ Weedy check (negative control).

Physiological Response: Leaf area ratio (LAR) at 3, 6 and 9 WAP in both varieties varied significantly $(\mathrm{P}<0.05)$ due to weed control methods (Table 4). At 3 WAP in both varieties, the highest value of LAR was recorded in three hand weeding at 3,6 and 9 WAP due to increase in above-ground dry weight value. This was followed in decreasing order by weed free, two hand weeding at 3 and $6 \mathrm{WAP}$, one hand weeding at 3 WAP and weedy check which had the minimum LAR. However, at 9 WAP, in Tvx 3236, there were no significant differences in the cowpea receiving on hand weeding at 3 WAP and weedy check. Relative Growth Rate (RGR) follows the same pattern as documented for LAR (Table 04).In addition, it was observed that declination in LAR and RGR were due to persistence increase in shedding of leaves and plant ageing. Similar trend was observed by Biswas et al., (2002), and Howard (2013) that reduction of leaf area ratio with age has been observed as a feature of annual plants.

OLAYINKA, BU; LAWAL, AR; ABDULBAKI, SA; AYINLA, A; OLADOKUN, LT; UDO, OF; AKINWUNMI, MA; ETEJERE, EO 
Table 4: Leaf area ratio and relative growth rate as affected by different weed control methods

\begin{tabular}{|c|c|c|c|c|c|c|c|}
\hline \multirow[t]{3}{*}{ Varieties } & \multirow[t]{3}{*}{ Treatment } & \multicolumn{3}{|c|}{$\begin{array}{l}\text { Leaf Area Ratio (LAR) } \\
\qquad\left(\mathrm{m} \mathrm{g}^{-1}\right)\end{array}$} & \multicolumn{3}{|c|}{$\begin{array}{l}\text { Relative Growth Rate (RGR) } \\
\qquad\left(\mathrm{g} \mathrm{g}^{-1} \text { day }^{-1}\right)\end{array}$} \\
\hline & & & Neeks A & anting $(\mathrm{W}$ & & & \\
\hline & & 3 & 6 & 9 & $0-3$ & $3-6$ & $6-9$ \\
\hline \multirow[t]{7}{*}{ Tvx 3236} & $\mathrm{~T}_{1}$ & $3.74^{\mathrm{d}}$ & $1.69^{d}$ & $1.13^{\mathrm{c}}$ & $0.045^{\mathrm{ab}}$ & $0.060^{\mathrm{d}}$ & $0.025^{\mathrm{d}}$ \\
\hline & $\mathrm{T}_{2}$ & $4.86^{\mathrm{c}}$ & $1.65^{\mathrm{c}}$ & $1.12^{\mathrm{b}}$ & $0.048^{\mathrm{a}}$ & $0.078^{\mathrm{c}}$ & $0.028^{\mathrm{c}}$ \\
\hline & $\mathrm{T}_{3}$ & $5.05^{\mathrm{b}}$ & $1.56^{\mathrm{b}}$ & $1.12^{\mathrm{b}}$ & $0.042^{\mathrm{b}}$ & $0.086^{\mathrm{b}}$ & $0.030^{\mathrm{b}}$ \\
\hline & $\mathrm{T}_{4}$ & $5.23^{\mathrm{a}}$ & $1.84^{\mathrm{a}}$ & $1.35^{\mathrm{a}}$ & $0.050^{\mathrm{a}}$ & $0.094^{\mathrm{a}}$ & $0.090^{\mathrm{a}}$ \\
\hline & $\mathrm{T}_{5}$ & $3.41^{\mathrm{e}}$ & $1.71^{\mathrm{e}}$ & $1.20^{\mathrm{c}}$ & $0.039^{c}$ & $0.092^{\mathrm{ab}}$ & $0.020^{\mathrm{e}}$ \\
\hline & Mean & 8.46 & 1.69 & 1.18 & 0.045 & 0.082 & 0.039 \\
\hline & p-value & $<0.001$ & $<0.001$ & 0.855 & $<0.001$ & $<0.001$ & $<0.001$ \\
\hline \multirow[t]{7}{*}{ Ife brown } & $\mathrm{T}_{1}$ & $3.82^{\mathrm{d}}$ & $1.56^{\mathrm{d}}$ & $1.18^{\mathrm{d}}$ & $0.044^{\mathrm{d}}$ & $0.082^{\mathrm{d}}$ & $0.023^{\mathrm{d}}$ \\
\hline & $\mathrm{T}_{2}$ & $5.02^{\mathrm{c}}$ & $1.58^{\mathrm{c}}$ & $1.19^{\mathrm{c}}$ & $0.046^{\mathrm{c}}$ & $0.090^{\mathrm{c}}$ & $0.025^{\mathrm{c}}$ \\
\hline & $\mathrm{T}_{3}$ & $5.30^{\mathrm{b}}$ & $1.66^{\mathrm{b}}$ & $1.20^{\mathrm{b}}$ & $0.047^{\mathrm{b}}$ & $0.094^{\mathrm{b}}$ & $0.029^{\mathrm{b}}$ \\
\hline & $\mathrm{T}_{4}$ & $5.41^{\mathrm{a}}$ & $1.71^{\mathrm{a}}$ & $1.32^{\mathrm{a}}$ & $0.051^{\mathrm{a}}$ & $0.096^{\mathrm{a}}$ & $0.034^{\mathrm{a}}$ \\
\hline & $\mathrm{T}_{5}$ & $3.79^{\mathrm{e}}$ & $1.55^{\mathrm{e}}$ & $1.17^{\mathrm{e}}$ & $0.040^{\mathrm{e}}$ & $0.062^{\mathrm{e}}$ & $0.010^{\mathrm{e}}$ \\
\hline & Mean & 8.47 & 1.61 & 1.21 & 0.046 & 0.085 & 0.024 \\
\hline & p-value & $<0.001$ & $<0.001$ & $<0.001$ & $<0.001$ & 0.002 & $<0.001$ \\
\hline
\end{tabular}

$\boldsymbol{N}$. BMeans in the same column having the same superscripts are not significantly different at $(P<0.05)$. $T_{I}=$ One hand weeding at $3 W A P$, $T_{2}=$ Two hand weeding at 3 and $6 \mathrm{WAP}, T_{3}=$ three hand weeding at 3,6 and $9 \mathrm{WAP}, T_{4}=$ Weed free (positive control) and $T_{5}=$ Weedy check (negative control).

Yield: The weed control treatments significantly $(\mathrm{p}<$ 0.05 ) affect the number of matured per plant and pod weight and pod yields in kilogram per hectare (Table 5). In both varieties, lowest values of yield attributes and yields were observed in weedy check compared to all other treatments. Highest value of 22.67 in Tvx 3236 and 26.00 in Ife brown of number of pods per plant were recorded from three hand weeding at 3,6 and $9 \mathrm{WAP}$. The same treatment also recorded highest values for pod weight per plant and pod yield in kilogram per hectare. The higher pod production recorded in two hand weeding at 3 and 6 WAP and three hand weeding at 3,6 and 9 WAP when compared to other weed control treatments could be attributed to removal of earlier and late weeds thereby avail the plants receiving these treatments adequate resources for pod growth and filling of the grain. Dugie, et al. (2009) had reported that weeding suppressed or minimized the growth, development and competitive capacity of weeds thereby enhancing optimum pod yield. Varietal difference showed that yield and yield attributes were higher in Ife brown than Tvx 3236. This could be attributed to differential genetic makeup of the crops (Hernandez et al., 2008; Olayinka and Etejere, 2015; Olayinka et al., 2017).

\begin{tabular}{|c|c|c|c|c|}
\hline Varieties & Treatment & $\begin{array}{l}\text { Number of } \\
\text { Pod per plant }\end{array}$ & $\begin{array}{l}\text { Weight of pods } \\
\text { per plant (g) }\end{array}$ & $\begin{array}{l}\text { Pod yield } \\
\text { (kg/ha) }\end{array}$ \\
\hline \multirow[t]{7}{*}{ Tvx 3236} & $\mathrm{~T}_{1}$ & $12.67^{\mathrm{d}}$ & $13.37^{\mathrm{d}}$ & $1337.00^{\mathrm{d}}$ \\
\hline & $\mathrm{T}_{2}$ & $18.33^{\mathrm{c}}$ & $18.70^{\mathrm{c}}$ & $1870.00^{\mathrm{c}}$ \\
\hline & $\mathrm{T}_{3}$ & $20.33^{\mathrm{b}}$ & $21.13^{\mathrm{b}}$ & $2113.00^{\mathrm{b}}$ \\
\hline & $\mathrm{T}_{4}$ & $22.67^{\mathrm{a}}$ & $24.47^{\mathrm{a}}$ & $2447.00^{\mathrm{a}}$ \\
\hline & $\mathrm{T}_{5}$ & $8.33^{\mathrm{e}}$ & $7.77^{\mathrm{e}}$ & $777.00^{\mathrm{e}}$ \\
\hline & Mean & 16.47 & 17.09 & 1708.00 \\
\hline & p-value & $<0.001$ & $<0.001$ & $<0.001$ \\
\hline \multirow{7}{*}{ Ife brown } & $\mathrm{T}_{1}$ & $12.67^{\mathrm{d}}$ & $13.87^{\mathrm{d}}$ & $1387.00^{\mathrm{d}}$ \\
\hline & $\mathrm{T}_{2}$ & $20.33^{\mathrm{c}}$ & $22.10^{\mathrm{c}}$ & $2210.00^{\mathrm{c}}$ \\
\hline & $\mathrm{T}_{3}$ & $22.67^{\mathrm{b}}$ & $25.17^{\mathrm{b}}$ & $2517.00^{\mathrm{b}}$ \\
\hline & $\mathrm{T}_{4}$ & $26.00^{\mathrm{a}}$ & $28.10^{\mathrm{a}}$ & $2810.00^{\mathrm{a}}$ \\
\hline & $\mathrm{T}_{5}$ & $9.33^{\mathrm{e}}$ & $9.43^{\mathrm{e}}$ & $943.00^{\mathrm{e}}$ \\
\hline & Mean & 18.20 & 19.73 & 1973.40 \\
\hline & p-value & $<0.001$ & $<0.050$ & $<0.001$ \\
\hline
\end{tabular}

N. B: Means in the same column having the same superscripts are not significantly different at $(\mathrm{P}<0.05)$. $\mathrm{T}_{1}=\mathrm{O}$ e hand weeding at $3 \mathrm{WAP}$, $\mathrm{T}_{2}=$ Two hand weeding at 3 and $6 \mathrm{WAP}, \mathrm{T}_{3}=$ three hand weeding at 3,6 and $9 \mathrm{WAP}, \mathrm{T}_{4}=$ Weed free (positive control) and $\mathrm{T}_{5}=\mathrm{Weedy}$ check (negative control).

Proximate Composition: The composition of the seeds in both varieties was significantly $(\mathrm{p}<0.05)$ influenced by weed control methods except for carbohydrate in Ife brown (Table 6). In both varieties, percentage ash, fibre, protein and fat were significantly higher in the weed control treatments compared to the weedy check. The reduction of these parameters in the weed check could be linked to competition of weeds with crop for scarce resources most importantly nutrients. In fact, plots receiving three hand weeding at 3,6 and 9 WAP and the weed free plots showed higher values of these aspect of

OLAYINKA, BU; LAWAL, AR; ABDULBAKI, SA; AYINLA, A; OLADOKUN, LT; UDO, OF; AKINWUNMI, MA; ETEJERE, EO 
proximate composition than two hand weeding at 3 and 6 WAP and one hand weeding at 3 WAP. Olayinka et al. (2013) had reported similar findings where higher ash, fibre, protein and fat were recorded in weed control treatments than the weedy check. Regardless of weed control treatments, proximate composition of the seed was higher in Ife-brown than Tvx 3236 except fibre and carbohydrate. Also, both varieties showed highest percentage values of carbohydrate (56.61-60.75\%) followed by protein (15.67-17.81\%), fibre (13.36-14.16\%), moisture (3.57 $-5.75 \%)$ ash $(3.78-4.17 \%)$ and fat $(2.08-2.31 \%)$. It should be noted that the two varieties were generally low in moisture content. This implies that the varieties under investigation will be less vulnerable to deterioration. The ash contents analysed ranged from $3.37-4.24 \%$. Similar range of values $(3.80-4.50 \%)$ were also reported by Inobeme et al., 2014 in cowpea. Higher ash content was recorded in weed free check when compared to other treatments in both varieties. Ife brown had higher ash content than Tvx 3236. Percentage crude fibre was affected due to frequency of hand weeding. In both varieties, the crude fibre content of the seeds ranged from $13.17-14.32 \%$ with the Tvx3236 seeds having the higher value (Table 06). The fibre content in relation to the diet is adequate, fibre intake have been reported to lower risk for developing; cardiovascular health disease, hypertension, diabetes, obesity, and certain gastrointestinal diseases. Increasing the intake of high fibre foods or fibre supplements improves serum lipoprotein values, lowers blood pressure, improves blood glucose control for diabetic individuals, aids weight loss, and improves the rhythmic wave-like contraction of the digestive tract (Ötles and Ozgoz, 2014). Higher crude protein was recorded in weed free check over all other treatments in both varieties. In both varieties, the crude protein content of the cowpea varieties ranged from $15.29-17.91 \%$ with the Ife brown seeds having the higher value. The variation in range noticed may be due to genetic variation. Cowpea meals are good sources of nutrients and can be used as ingredients in diets (Rivas-Vega et al., 2006). In both varieties, the highest percentage fat content value was recorded under three hand weeding plot (3,6 and 9) and weed free plot in Tvx 3236 and Ife brown respectively the variation in fat content could be due to genetic makeup. The observed range value (2.02$2.46 \%$ ) of fat in this study is in conformity with the low fat content also observed by Aaron et al. (2013). The carbohydrate content analyzed ranged from $56.20-61.66 \%$ with the Tvx 3236 seeds having the higher value. Significant higher carbohydrate was recorded in weedy check plot over all other treatments in both varieties, while the least value was found under weed free plot. Carbohydrates are good source of energy (Suman et al., 2008).

Table 6: Proximate composition of two varieties of cowpea as influenced by frequency of hand weeding

\begin{tabular}{|c|c|c|c|c|c|c|c|}
\hline Variety & Treatment & Moisture & Ash & Crude fibre & Protein & Fat & Carbohydrate \\
\hline \multirow{7}{*}{ Tvx 3236} & $T_{1}$ & $3.68^{\mathrm{b}}$ & $3.63^{\mathrm{d}}$ & $1407^{\mathrm{c}}$ & $\begin{array}{l}-\% \\
1559^{\mathrm{d}}\end{array}$ & $205^{\mathrm{d}}$ & $6098^{\mathrm{b}}$ \\
\hline & $\mathrm{T}_{2}$ & $3.58^{\mathrm{c}}$ & $\begin{array}{l}3.03 \\
3.83^{\mathrm{c}}\end{array}$ & $14.19^{\mathrm{b}}$ & $\begin{array}{l}15.59^{\mathrm{c}} \\
15.75^{\mathrm{c}}\end{array}$ & $2.08^{\mathrm{c}}$ & $\begin{array}{l}00.98 \\
60.58^{\mathrm{bc}}\end{array}$ \\
\hline & $\mathrm{T}_{3}$ & $3.45^{\mathrm{d}}$ & $3.98^{\mathrm{b}}$ & $14.32^{\mathrm{a}}$ & $15.80^{\mathrm{b}}$ & $2.14^{\mathrm{a}}$ & $60.37^{\mathrm{c}}$ \\
\hline & $\mathrm{T}_{4}$ & $3.39^{\mathrm{e}}$ & $4.08^{\mathrm{a}}$ & $14.28^{\mathrm{a}}$ & $15.91^{\mathrm{a}}$ & $2.11^{\mathrm{b}}$ & $60.17^{c}$ \\
\hline & $\mathrm{T}_{5}$ & $3.75^{\mathrm{a}}$ & $3.37^{\mathrm{e}}$ & $13.93^{\mathrm{d}}$ & $15.29^{\mathrm{e}}$ & $2.02^{\mathrm{e}}$ & $61.66^{\mathrm{a}}$ \\
\hline & Mean & 3.57 & 3.78 & 14.16 & 15.67 & 2.08 & 60.75 \\
\hline & $\mathrm{p}$-value & 0.003 & $<0.001$ & $<0.001$ & $<0.001$ & $<0.001$ & $<0.001$ \\
\hline \multirow[t]{7}{*}{ Ife brown } & $\mathrm{T}_{1}$ & $5.83^{\mathrm{b}}$ & $4.14^{\mathrm{d}}$ & $13.17^{\mathrm{d}}$ & $17.74^{\mathrm{d}}$ & $2.13^{\mathrm{d}}$ & $56.77^{\mathrm{a}}$ \\
\hline & $\mathrm{T}_{2}$ & $5.78^{\mathrm{c}}$ & $4.17^{\mathrm{c}}$ & $13.37^{\mathrm{bc}}$ & $17.80^{\mathrm{b}}$ & $2.31^{\mathrm{c}}$ & $56.65^{\mathrm{a}}$ \\
\hline & $\mathrm{T}_{3}$ & $5.57^{\mathrm{e}}$ & $4.21^{\mathrm{b}}$ & $13.45^{\mathrm{ab}}$ & $17.83^{\mathrm{c}}$ & $2.38^{\mathrm{b}}$ & $56.45^{\mathrm{a}}$ \\
\hline & $\mathrm{T}_{4}$ & $5.65^{\mathrm{d}}$ & $4.24^{\mathrm{a}}$ & $13.55^{\mathrm{a}}$ & $17.91^{\mathrm{a}}$ & $2.46^{\mathrm{a}}$ & $56.20^{\mathrm{a}}$ \\
\hline & $\mathrm{T}_{5}$ & $5.90^{\mathrm{a}}$ & $4.10^{\mathrm{e}}$ & $13.27^{\mathrm{cd}}$ & $17.73^{\mathrm{d}}$ & $2.27^{\mathrm{c}}$ & $56.96^{\mathrm{a}}$ \\
\hline & Mean & 5.75 & 4.17 & 13.36 & 17.81 & 2.31 & 56.61 \\
\hline & $\mathrm{p}$-value & $<0.001$ & $<0.001$ & $<0.001$ & $<0.001$ & $<0.001$ & 0.855 \\
\hline
\end{tabular}

N.B: Means in the same column having the same superscripts are not significantly different at $(P<0.05) . T_{I}=$ One hand weeding at $3 W A P$, $T_{2}=T$ wo hand weeding at 3 and $6 \mathrm{WAP}, T_{3}=$ three hand weeding at 3, 6 and $9 \mathrm{WAP}, T_{4}=$ Weed free (positive control) and $T_{5}=$ Weedy check (negative control).

Conclusion: The results of this study had established that all the weed control treatments were effective in suppressing weed growth and improving growth, yield and some aspect of proximate composition of seeds such as ash, fibre, protein and fat. However, the use of two and three hand weeding are considered optimum and suitable for methods of controlling weeds due to their positive influence on growth, yield and quality of the grains in the two varieties of cowpea studied.

\section{REFERENCES}

Aaron, TA; Robert, A; Genevieve, EA; Emmanuel, D; Kingsley, AA (2013).Assessment of functional properties and nutritional composition of some cowpea (Vigna unguiculata L.) genotypes in Ghana. ARPN J. Agric. Bio. Sci. 8(6): 465-469.

OLAYINKA, BU; LAWAL, AR; ABDULBAKI, SA; AYINLA, A; OLADOKUN, LT; UDO, OF; AKINWUNMI, MA; ETEJERE, EO 
Akobundu, IO (2005). Chemical weed control in cowpea and soybean in southern Nigeria. In: Zene Symposium Surle Desherbage de cultures tropicales. 475-482.

Anikwe, MAN; Ubochi, JN (2007). Short-term changes in soil properties under tillage systems and their effect on sweet potato (Ipomeabatatas, L.) growth and yield in ultisol in south-western Nigeria. Australian J. Soil Res.45: 351-358.

AOAC (2000). Official methods of analysis. 7th ed. Washington, USA:Association of Official Analytical Chemists.

Ayodele, JT; Yalwa, IR (2005). Amino acid composition of Vigna dekindtiana. Bio. Environ. Sci. J. Trop.2(1): 62-66.

Bhan, VM; Balysan, RS; Singh, SP (2003). Influence of time of weed removal and weed species on the grain yield of cowpea. Indian J. Agron., 25(4): 364-369.

Biswas, DK; Haque, MM; Hamid, A; Ahmed, IU; Rahman, MA (2002). Influence of plant population density on growth and yield of two varieties of blackgram. Pakistan J. Agro. 1 (2-3): 83-85.

Dadari, SA (2003). Evaluation of herbicides in cowpea/cotton mixture in northern guinea savannah. J. Sustain. Agric. Environ.5: 153-159.

Dugie, IY; Omoigui, LO; Ekeleme, F; Bandyopakhyay, R; Kumar, PL; Kamara, AY (2009). Farmers Guide to Soybean Production in Nigeria. Ibadan, Nigeria: International Institute of Tropical Agriculture. 21pp.

Getachew, M; Sharma, JJ; Lisanework, N; Tamado, T (2017). Effect of planting pattern and weeding frequency on weed infestation, yield components and yield of cowpea [Vignaunguiculata (L.) Walp.] in Wollo, northern Ethiopia. Agric. Forest. Fish. 6(4): 111-122.

Hernández, M; Morgante, V; Flores, C; Villalobos, P; González, M; Miralles, P; Dinamarca, A; Seeger, M (2008). Modern approaches for the study of striazine herbicide bioremediation in agricultural soils. J. Soil Sci. Plant Nutr. 8 (2): 19-30.

Howard, T (2013). Senescence, ageing and death of the whole plant. New Phytologist. 197: 696-711.
Inobeme, A; Inlemadim, AB; Obigwa, PA; Ikechukwu, G;Ajai, AI (2014). Proximate and mineral compositions of white cowpea beans (Vigna unguiculata) collected from markets in Minna, Nigeria. Inter. J. Sci. Engr. Res. 5 (8): 2229-5518.

Khan, I; Hassan, G; Khan, MA; Khan, IA (2004). Efficacy of some new herbicidal molecules on grassy and broad leaf weeds in wheat crop-II. Pakistan J. Weed Sci. Res. 10 (1-2): 33-38.

Mathew, G; Screenivasan, E (1998). Effect of weed control methods on yield and yield economics of rain fed and rice fallow summer cowpea. Madras Agric. J. 85: 50-52.

Muoneke, CO; Ndukwe, OO; Umana, PE; Okpara Asawalam, DO (2012). Effect of relative sowing time on growth and yield of vegetable cowpea (Vigna unguiculata) and maize intercropping system. J. Agric. Sci. Environ. 12(1): 1-14.

Odeleye, FO; Odeleye, OMO; Data, OA (2007). The performance of soybean (Glycine max (L.) under varying weeding regimes in south-western Nigeria. Notulae Bot. Horti Agrobot. ClujNapoca 35 (1): 1842-4309.

Ogbuinya, PO (1997). Advances in cowpea research. Biotech. Develop. Monitor. 33: 10-12.

Olayinka BU; Etejere, EO (2013). Influence of weed management strategies on proximate composition of two varieties of groundnut (Arachis hypogaea, L.). Annals. Food Sci. Technol.14 (2): 286-293.

Olayinka, BU; Etejere, EO (2015). Growth analysis and yield of two varieties of groundnut (Arachis hypogaea, L.) as influenced by different weed control methods. India J. Plant Phys. 20 (2): 130136

Olayinka, BU; Esan, OO; Anwo, IO; Etejere, EO (2017). Comparative growth analysis and fruit quality of two varieties of tomato under hand weeding and pendimenthalin herbicide. J. Agric. Sci.12 (3): 149-161.

Ötles, S; Ozgoz, S (2014). Health effects of dietary fibre. Acta Sci. Polonorum Technol. Alimentara 13 (2): 191-202.

Padulosi, S; Ng, NQ (1997). Origin, taxonomy, and morphology of Vigna unguiculata (L.) Walp. In: B. B. Singh, D. R. Mohan Raj, K. E. Dashiell, L.

OLAYINKA, BU; LAWAL, AR; ABDULBAKI, SA; AYINLA, A; OLADOKUN, LT; UDO, OF; AKINWUNMI, MA; ETEJERE, EO 
E. N. Jackai, (Eds). Advances in cowpea research. Co-publication (IITA) and Japan International Research Center for Agricultural Science (JIRCAS), Sayee, Devon, U.K. 1-12.

Rachman, A; Anderson, SH; Gantzer, CJ; Thompson, AL (2003). Influence of long-term cropping systems on soil physical properties related to soil credibility. Soil Sci. Soc. America J. 67: 637-644.

Reddy, KN; Whiting, K (2000). Weed control and economic comparisons glyphosate resistant, sulfonylurea-tolerant, and conventional soybean (Glycine max) systems. Weed Sci. Soc. America. 14: 204-211. unguiculata, (L.) Walp] meals as ingredients in diets for pacific white shrimp (Litopenaeus vannamei, Boone). Food Chem. 97 (1): 41-49.

Singh, BB (2002). Recent genetic studies in cowpea. In: Fatokun, CA; Tarawali, SA; Singh, BB; Kormawa, PM; Tamo, M. (Eds) Challenges and opportunities for enhancing sustainable cowpea production. IITA, Ibadan, Nigeria. 3-13.

Suman, K; eepak, V; Samudra, PB (2008). Biomolecules: (introduction, structure \& function) carbohydrates. Drug Development and Biotechnology. Indian Institute of Chemical Biology 4, Kolkata- India.

Rivas-Vega, ME; Goytortúa-Bores, E; EzquerraBrauer, JM; Salazar-García, MG; Cruz-Suárez, LE; Nolasco, H; Civera-Cerecedo, R (2006). Nutritional value of cowpea [Vigna

OLAYINKA, BU; LAWAL, AR; ABDULBAKI, SA; AYINLA, A; OLADOKUN, LT; UDO, OF; AKINWUNMI, MA; ETEJERE, EO 